\title{
O PROTESTO DAS CERTIDÕES DE DÍVIDA ATIVA MUNICIPAL DE ACORDO COM A LEI № 12.767/2012
}

\author{
Nauana Franco da Silva ${ }^{1}$ \\ Marcelo Terra Reis ${ }^{2}$
}

Resumo: $O$ presente artigo tem como objetivo analisar a possibilidade do protesto das certidões de dívida ativa municipal. Considerando a alteração da Lei no 12.767/2012, deve ser levado em consideração as maneiras para realizar o protesto da dívida ativa, visando à celeridade e facilidade para o procedimento, tendo em vista que no processo de execução, essa cobrança se prolongaria por muito tempo, devendo ser considerados os princípios da celeridade processual e a desjudicialização da execução fiscal, visando à resolução extrajudicial das demandas preconizada pela entrada em vigor do novo Código de Processo Civil. Serão expostos aqui, posicionamentos e conceituações doutrinárias de suma importância para a elucidação do tema elencado. Por fim, a pesquisa aponta que os Municípios têm a possibilidade do protesto da certidão de dívida ativa municipal, e que depois de protestada, a mesma pode ser executada judicialmente.

Palavras-chave: Protesto. Dívida ativa municipal. Lei ํㅜ 12.767/2012.

Abstract: The present article has the purpose the analysis of possibility to protest municipal's debt certificates. Whereas the emendment to Law 12.767/2012, considerating the methods to realize the protest of those debts, in order to speed up and ease the procedure, at the execution process this collection would be prolonged for a long time, and should be considerated the principles of process celerity and the avoiding of trials in taxes collection, in order to resolve litigation out of Court in accordance with the new civil process law. In this article will be exposed doctrinal positions and conceptualizations of great relevance to elucidate the subject. Finally, the research points out that the Municipalities has the possibility of protest the debt's certificates, and after that being protested, it can be executed in Court.

Key Words: Protest. Municipal active debt. Law no 12.767/2012.

\footnotetext{
${ }^{1}$ Acadêmica do curso de Direito da UNICNEC/OSÓRIO.

${ }^{2}$ Advogado e Professor Universitário. Coordenador do Curso de Direito da UNICNEC. Pró-Reitor de Relações Comunitárias da UNICNEC. Mestre em Desenvolvimento Regional pela FACCAT.
} 


\section{INTRODUÇÃO}

O presente estudo versa sobre à prática do procedimento desde 0 apontamento da CDA, a intimação, a devolução, retirada e se necessária o protesto, e tem a finalidade de compreender sua nova roupagem jurídica e sua aplicabilidade, tendo em vista as mudanças advindas do novo texto da lei. O protesto é uma ferramenta célere e eficaz no sentido de resgatar dívidas inadimplentes. Desde que o provimento no 19/2014 da Corregedoria Geral da Justiça do Rio Grande do Sul, entrou em vigor, existe a possibilidade do protesto de Certidão de Dívida Ativa.

O presente tema merece uma análise, considerando a facilidade do procedimento junto ao tabelionato de protesto. Com a existência dessa alternativa, precisa-se de um estudo de como na prática ficará o procedimento a partir da inserção dessa nova possibilidade. Com o protesto da CDA, o contribuinte terá limitação do seu crédito, pois somente a emissão da CDA não the causa dano ou restrição alguma, e se protestado o mesmo vai se encontrar negativado nos órgãos de proteção ao crédito, tais como, SPC, SERASA, dentre outros.

Para tanto, este artigo é dividido em cinco tópicos. O primeiro deles é a introdução. O segundo trata do Tabelião, e sua responsabilidade civil, bem como sobre a responsabilidade civil específica dos tabeliães de protesto. $O$ terceiro tópico é referente ao Protesto, seu conceito, natureza jurídica e características. O quarto tópico trará sobre Imposto Predial e Territorial Urbano - IPTU, e certidão de dívida ativa. Já o quinto tópico será sobre as inovações da Lei 12.767/2012. E o sexto tópico será referente ao procedimento do protesto, o apontamento, a intimação, o cancelamento, a desistência e a sustação. Ao final, tratamos das considerações finais, que irá encerrar a presente pesquisa.

O estudo aqui tratado terá como base principal a pesquisa bibliográfica e documental, coletando dados por meio da legislação, doutrina, artigos jurídicos e pesquisas online, e terá o objetivo principal de demonstrar a importância e eficácia do protesto da certidão de dívida ativa municipal, seu papel no plano jurídico e as alterações trazidas pela Lei. O que se pretende, é que, ao final da leitura do 
presente artigo, o leitor consiga compreender com clareza esses aspectos, contribuindo para o seu crescimento intelectual no assunto.

\section{O TABELIÃO E A ATIVIDADE NOTARIAL}

Ocorreram profundas mudanças no direito notarial brasileiro a partir da vigência da Constituição Federal de 1988. Até então, pouco havia mudado em relação propriamente à função notarial desde o primeiro diploma. Com a edição da nova Carta Magna, foram lançadas, no seu artigo ํㅡ 236, as diretrizes básicas para a regulamentação da atividade notarial e registral, estabelecendo a necessidade de legislação específica para a classe ${ }^{3}$, e as características de serviço público delegado, fazendo com que, então, houvesse um sistema de organização com a delimitação de seus poderes e atribuições.

A definição da atividade notarial pode ser apontada nas palavras do Excelentíssimo Juiz Diretor do Foro de Porto Alegre Giovanni Conti, no parecer prolatado no Expediente no 040111-03.00/07-0, de 2007, in verbis

[...] atualmente a legislação sobre a atividade notarial e registral está consolidada. Inúmeras foram às mudanças e a principal delas adveio com a promulgação da Constituição em 1988, que no artigo 236 definiu os serviços notariais e de registro como sendo uma delegação pública, exercida em caráter privado, com ingresso através de concurso público de provas e títulos, sendo necessário para o seu desempenho o grau de bacharel em direito.

Posteriormente, a lei 8.935/1994 regulamentou a atividade definindo os deveres, obrigações e responsabilidades dos notários e registradores. Dentre as principais definições, destacamos que os titulares mantêm por sua conta e risco os seus serviços em funcionamento, pagam seus funcionários, investem em melhorias na estrutura dos seus locais de atendimento, modernizam seus sistemas de informática e, principalmente, respondem civil e criminalmente com seus bens pessoais, pelas perdas e danos que venham causar as partes.

Em essência, o Tabelião e o Registrador são profissionais do direito, com formação jurídica, dotados de fé pública, que previne litígios entre as partes e imprime segurança aos atos que pratica. É seu dever atender as partes com isenção e imparcialidade, aconselhando e orientando, transmitindo tranqüilidade, equilíbrio e segurança aos atos jurídicos. Ele não induz, sugere ou determina o que o cliente deve fazer, apenas expõe o que é legal e imprime juridicamente à vontade das partes e, principalmente, atende e orienta gratuitamente os que lhe procuram, servindo a sua comunidade.

\footnotetext{
${ }^{3}$ BRANDELLI, Leonardo. Teoria Geral do Direito Notarial. 2. ed. São Paulo: Saraiva, 2007. p. 7.
} 
Portanto, é um profissional indispensável à sociedade e segurança jurídica, pois contribui efetivamente com a sua comunidade, procurando prevenir litígios e evitar conflitos jurídicos.

Nesta seara, o entendimento predominante de nossa doutrina e jurisprudência firmam a posição de que os cartórios (ou ofícios) extrajudiciais constituem unidades de serviços notariais ou registrais que não são dotadas de personalidade jurídica e que, por concurso público, se atribuem à determinada pessoa, a fim de que esta, titularizando o cartório, por delegação do Poder Público, desempenhe suas atividades funcionais. ${ }^{4}$

Segundo a legislação vigente, que tem o escopo de reger a atividade notarial, temos, em âmbito federal, a Lei no 8.935/94, editada como Lei complementar ao disposto no artigo no 236 da magna carta, estabeleceu, nos artigos $6^{\circ}$ e $7^{\circ}$ daquele diploma, a limitação da atividade notarial, em termos genéricos. $O$ art $6^{0^{5}}$ do referido texto legal indica que cabe ao notário, porém sem exclusividade, a formalização da vontade das partes, a participação deste nos atos e negócios jurídicos que as partes desejam, além de autenticar fatos.

O Juiz Luís Paulo Aliende Ribeiro diz que:

Os notários e registradores, embora exercentes de função pública, não são funcionários públicos, nem ocupam cargos públicos efetivos, tampouco se confundem com os servidores e funcionários públicos integrantes da estrutura administrativa estatal, por desempenharem função que somente se justifica a partir da presença do Estado - o que afasta a idéia de atividade exclusivamente privada, inserem-se na ampla categoria de agentes públicos, nos termos acolhidos de forma pacífica pela doutrina brasileira de direito administrativo. ${ }^{6}$

\section{O autor Luis Paulo Aliende Ribeiro traz em sua obra:}

A outorgada da delegação de notas e de registro á pessoal natural guarda correspondência com a atividade jurídica relativa a tais profissões oficiais

\footnotetext{
${ }^{4}$ PORTO ALEGRE. Foro da Comarca. Expediente no 040111-03.00/07-0, de 07 de agosto de 2007. Expediente instaurado em razão das inúmeras reclamações. Porto Alegre, 07 de agosto de 2007. Disponível em: <http://www.12tabelionato.com.br/download/determinacoes_juiz_diretor_foro_porto_ alegre.pdf>. Acesso em: 28 maio 2017.

${ }^{5}$ Art 6ㅇ. Aos notários compete:

I - formalizar juridicamente a vontade das partes;

II - intervir nos atos e negócios jurídicos a que as partes devam ou queiram dar forma legal ou autenticidade, autorizando a redação ou redigindo instrumentos adequados, conservando os originais e expedindo cópias fidedignas de se conteúdo;

III - autenticar fatos.

${ }^{6}$ RIBEIRO, Luís Paulo Aliende. Regulação da função pública notarial e registral. São Paulo: Saraiva, 2009. p. 42.
} 
(ou profissões públicas independestes). A aferição da capacitação do profissional de direito por meio de concurso e provas de títulos é requisito necessário não somente para a constatação de que o candidato possui o conhecimento jurídico necessário ao desempenho de tais atribuições, mas também para o atendimento do comando constitucional que a impõem, para o ingresso em qualquer função pública. ${ }^{7}$

Nos artigos $\mathrm{n}^{0} 14$ a 19 da Lei $\mathrm{n}^{\circ}$ 8.935/94, com regulamentação pela Resolução 81, de 09 de junho de 2009 do Conselho Nacional de Justiça, nos traz sobre o concurso e os outros requisitos para outorga por delegação, a qual se dá a investidura, com o início do exercício da atividade.

Em cada Tabelionato há apenas um Tabelião, o qual recebeu a outorgada na forma da lei. Conforme ( $\S 5$, do artigo no 20 , da Lei no 8.935/94) o Tabelião tem a possibilidade de nomear um substituto para the representar na sua ausência ou impedimento.

Ao analisar a referida Lei ํㅗ 8.935/94, podemos ver que está demonstra um padrão, ou seja, nela esta claro que quem registra é chamado oficial ou registrador, e quem lavra é tabelião ou notário.

A Lei ํㅜ 9.492/97, em seu artigo 3ํㅡ, traz as atribuições do Tabelião de Protesto ao dizer que compete a ele privativamente:

\footnotetext{
A protocolização, a intimação, o acolhimento de devolução ou aceite, o recebimento do pagamento, do titulo e de outros documentos de dívida, bem como lavrar e registrar o protesto ou acatar a desistência do credor em relação ao mesmo, proceder as averbações, prestar informações e fornecer certidões relativas a todos os atos praticados, na forma desta Lei. ${ }^{8}$
}

A pratica dessas atribuições é privativa, apenas o Tabelião de Protesto tem o poder para delas de desincumbir, ou seja, não pode ser um agente público, ou outro notário ou registrador.

${ }_{8}^{7}$ Ibidem, p. 54.

BRASIL. Lei no 9.492, de 10 de setembro de 1997. Define competência, regulamenta os serviços concernentes ao protesto de títulos e outros documentos de dívida e dá outras providências. Disponível em: <https://www.planalto.gov.br/ccivil_03/leis/L9492.htm>. Acesso em: 04 maio 2017. 
Nesse mesmo sentido comenta o autor Vicente Amadei: "Logo se vê que a testificação do protesto não pode ficar a cargo de qualquer um, mais sim de alguém que esteja em condições de imprimir ao seu testemunho a marca da fé pública."9

Sendo todas as atribuições do Tabelião de Protesto geradoras de graves efeitos, necessitando o mesmo estudo e aperfeiçoamento visando cumprir com segurança sua atividade. Por isso, é profissional do direito, assim definido no artigo $3^{\circ}$ da Lei $n^{\circ} 8.935 / 94$, "Notário, ou tabelião, e oficial de registro, ou registrador, são profissionais do direito, dotados de fé pública, a quem é delegado o exercício da atividade notarial e de registro." 10

Para o autor Sergio Luiz José Bueno:

\begin{abstract}
Se o Tabelião tem os direitos assegurados no artigo $n^{\circ} 29$ da Lei $n^{\circ}$ 8.935/94, deve atenção aos muitos deveres por ela impostos em seu artigo № 30. Assim, há de manter em rigorosa ordem os livros e papéis sob sua guarda, dedicando-se a atender ás partes com eficiência e presteza, sempre com urbanidade e respeito aquele que busca seus serviços. Deve perceber de forma a dignificar a função exercida, tanto nas atividades profissionais como na vida privada, e observar os emolumentos fixados para a prática dos atos do seu ofício. Esse entre muitos outros são deveres do Tabelião. ${ }^{11}$
\end{abstract}

O artigo $\mathrm{n}^{\circ} 30$ em seu inciso $\mathrm{VI}$, da Lei $\mathrm{n}^{\circ}$ 8.935/94, traz sobre "guardar sigilo sobre a documentação e os assuntos de natureza reservada de que tenham conhecimento em razão do exercício de sua profissão."12 Este assunto ganha muita ênfase com relação a atividade do protesto, pois é restrita a publicidade dos atos praticados em decorrência dela, como por exemplo, não se pode expedir certidão de protesto cancelado, se não por requerimento do devedor ou ordem judicial. descumprimento dessa norma pode gerar responsabilidade administrativa ao Tabelião.

9 AMADEI, Vicente de Abreu; DIP, Ricardo (Coord.) et al. Introdução ao direito notarial e registral. Porto Alegre: Fabris, 2004. p. 92.

10 BRASIL. Lei no 8.935, de 18 de novembro de 1994. Regulamenta o art. 236 da Constituição Federal, dispondo sobre serviços notariais e de registro. (Lei dos cartórios). Disponível em: <http://www.planalto.gov.br/ccivil_03/leis/L8935.htm>. Acesso em: 29 maio 2017.

11 BUENO, Sergio Luiz Jose. Tabelionato de Protesto. São Paulo: Saraiva, 2013. p. 131.

12 BRASIL. Lei no 8.935, de 18 de novembro de 1994. Regulamenta o art. 236 da Constituição Federal, dispondo sobre serviços notariais e de registro. (Lei dos cartórios). Disponível em: <http://www.planalto.gov.br/ccivil_03/leis/L8935.htm>. Acesso em: 30 maio 2017. 


\subsection{Responsabilidade civil dos notários e registradores}

Existe um grande debate com relação à responsabilidade civil do Tabelião de Protesto, sendo necessário primeiramente observar quanto à responsabilidade civil dos notários e registradores em geral, e posteriormente no tocante na área do protesto.

Conforme artigo no 22, da Lei no 8.935/94:

Os notários e oficiais de registro responderão pelos danos que eles e seus prepostos causem a terceiros, na prática de atos próprios da serventia, assegurado aos primeiros direitos de regresso no caso de dolo ou culpa dos prepostos. ${ }^{13}$

Nesse sentido a Constituição Federal traz em seu artigo ํำ 37, §6o o seguinte:

As pessoas jurídicas de direito público e as de direito privado prestadoras de serviços públicos responderão pelos danos que seus agentes, nessa qualidade, causarem a terceiros, assegurado o direito de regresso contra o responsável nos casos de dolo ou culpa. ${ }^{14}$

Em seu voto na proferida Apelação Cívil 170.183-5-9, o Desembargador Ricardo Dip, manifesta-se com relação ao artigo $\mathrm{n}^{0} 22$ da Lei dos Notários e Registradores:

Dessa maneira, os prejudicados por danos originários de atos dos notários, registradores ou seus prepostos podem eleger a vida de reparação contra o Poder Público ou a trilha da responsabilização subjetiva, provendo culpa ou dolo contra o delegado. E o Poder Público assegura a norma constitucional direito de regresso contra o responsável, por igual, com prova de dolo ou culpa. ${ }^{15}$

Observando o artigo acima citado, sendo agente público, o notário ou registrador, apenas responde se agir com dolo ou culpa. O Estado é que responderá

${ }^{13}$ BRASIL. Lei no 8.935, de 18 de novembro de 1994. Regulamenta o art. 236 da Constituição Federal, dispondo sobre serviços notariais e de registro. (Lei dos cartórios). Disponível em: <http://www.planalto.gov.br/ccivil_03/leis/L8935.htm>. Acesso em: 31 maio 2017.

14 BRASIL. Constituição da Republica Federativa do Brasil de 1998. Disponível em: <https://www.planalto.gov.br/ccivil_03/constituicao/constituicao.htm>. Acesso em: 12 out. 2016.

15 TJSP, Ap. Cível 170.1835-9, Rel. Des. Ricardo Dip. 
de forma objetiva, caso seja acionado judicialmente pela parte que se sentir prejudicada.

\subsection{Responsabilidade civil específica do tabelião de protesto}

Mesmo não sendo necessário por todo conhecimento doutrinário e jurisprudencial que se tem sobre o referido tema, a Lei $n^{0}$ 9.492/97, que o legislador editou pela correta interpretação do artigo $\mathrm{n}^{-}$22, da Lei dos Notários e Registradores, em concordância com o artigo nำ37, §6ํ da Constituição Federal, dispõem expressamente que os Tabeliães de protesto respondem pelos danos que causarem por dolo ou culpa.

O legislativo ao aprovar a Lei no 8.935/94, criou uma grande discussão doutrinária com relação ao tema, e com o artigo nº 38 da Lei do Protesto, tenteou explicitar sua vontade, buscando afastar dúvidas sobre a natureza da responsabilidade, assim dispondo:

Os Tabeliães de Protesto de Títulos são civilmente responsáveis por todos os prejuízos que causarem, por culpa ou dolo, pessoalmente, pelos substitutos que designarem ou Escreventes que autorizarem, assegurado 0 direito de regresso. ${ }^{16}$

O autor Luiz Emygdio F. da Rosa Jr, comenta sobre o artigo no 38 da Lei 9.492/97: "a responsabilidade do oficial decorre, portanto, de sua culpa ou dolo na execução do protesto, quando não o tenha lavrado no prazo legal ou por ter deixado ele observar a forma prescrita em lei."17 O Tribunal de Justiça do Rio de Janeiro decidiu que: "a responsabilidade do titular de cartório extrajudicial é verificada na modalidade subjetiva, de forma que para sua verificação deve ser comprovada ao menos a culpa."18

${ }^{16}$ BRASIL. Lei no 9.492, de 10 de setembro de 1997. Define competência, regulamenta os serviços concernentes ao protesto de títulos e outros documentos de dívida e dá outras providências. Disponível em: <https://www.planalto.gov.br/ccivil_03/leis/L9492.htm>. Acesso em: 31 maio 2017.

17 ROSA JUNIOR, Luiz Emygdio Franco da. Títulos de Crédito. 4. ed. Rio de Janeiro: Renovar, 2006. p. 402.

18 TJRJ, Ap. Cívil 0132505-98.2010.8.19.0001, Rel. Des. Maria Augusta Vaz.

\section{DIREITO, CULTURA E CIDADANIA}

Osório, v. 7, n. 1, 2017 
Conforme o artigo № 9o da Lei 9.492/97, não é dever do Tabelião do Protesto investigar a ocorrência da prescrição, assim, se não questionados os requisitos formais dos títulos, não há do que se falar em responsabilidade do Tabelião. Ou seja, o Tabelião não deve ser responsabilizado pela má-fé do apresentante, nem por algum erro que este possa cometer. Se o Tabelião cumprir corretamente sua função, sem identificar vícios formais que possam obstar o protesto, mesmo que o ato cause dano a qualquer das partes, o delegatário não deve ser responsabilizado por ele.

Dessa forma, com base na doutrina e na jurisprudência, está claro que a responsabilidade civil do Tabelião de Protesto é subjetiva. Podendo ser o apresentante do titulo responsabilizado em caso de abuso, ou má-fé, salvo se o Tabelião agir com dolo ou culpa.

\section{O PROTESTO}

O Protesto é ato formal e solene, pelo qual se prova a inadimplência e o descumprimento de obrigações baseada em títulos e outros documentos de dívida, como se depreende da leitura do artigo $1^{\circ}$ da Lei $n^{\circ}$ 9.492/1997. Sendo tal definição a respeito ao ato de protesto e não ao procedimento de protesto. Desta forma, é correto afirmar que tal processo tem por fim confirmar aquela inadimplência, ou que, o credor ao buscar a alternativa do protesto, tenha esse objetivo.

Para Pontes de Miranda:

Protesto é definido como sendo ato extrajudicial, formal e essencialmente probatório, através do qual se salvaguardam direitos cambiariformes, formalizado perante o Oficial Público, de serviços públicos, exercido em caráter privado, embora lotado por delegação do poder público e detentor de fé pública, como maneira de conservar e ressalvar direitos. ${ }^{19}$

Fabio Ulhoa Coelho, ao analisar o artigo 1ํ da Lei № 9.492/1997, define protesto como sendo ato praticado pelo credor, perante o serviço Notarial competente, para fins de incorporar ao título de crédito a prova de fato relevante

19 MIRANDA, Pontes de. Tratado de direito cambiário: duplicata mercantil. 2. ed. Atualizador: Vilson Rodrigues Alves. Campinas: Bookseller, 2001. V. 3. p. 326. 
para as relações cambiais. ${ }^{20}$ Fran Martins, por sua vez, afirma que o protesto é o ato solene destinado principalmente a comprovar a falta de recusa do aceite ou do pagamento da letra. ${ }^{21}$

Em última análise o autor Marlon Tomazette, tem o seguinte entendimento:

Protesto trata-se de um meio de prova especialíssimo, que goza de presunção, a princípio, inquestionável do fato demonstrado. O protesto não cria direitos, é apenas um meio especialíssimo de prova. Ele também não deve ser confundido com um meio de cobrança, pois trata-se exclusivamente de um meio de prova de fato relevante. ${ }^{22}$

Portanto, o protesto é ato solene, que tem como característica principal demonstrar que o devedor não cumpriu regularmente a obrigação constante no título cambial.

Observando a natureza do protesto, verifica-se que estamos à frente de ato jurídico, público, extrajudicial, formal, unitário e misto.

O protesto não é caracterizado como ato administrativo, pois necessita de pressupostos como finalidade e motivo, que deve ter uma ligação com o interesse público, não indiretamente, mas imediata.

Apesar de não ser ato administrativo, o protesto é ato público, em consequência, oficial. Conforme artigo no 236 da Constituição Federal os serviços notariais e de registro são exercidos em caráter privado, por delegação do Poder Público. ${ }^{23}$ Conforme a lei entende-se que o serviço oferecido por notários e registradores é público, sendo desempenhado em caráter privado.

Lavra-se o protesto sem que haja autorização judicial. Assim em situações ordinárias, o protesto e o procedimento que a ele conduz são extrajudiciais ${ }^{24}$. Salvo em ocasiões especiais, como por exemplo, a sustação dos efeitos do protesto, mas

20 COELHO, Fabio Ulhoa. Curso de Direito Comercial. 3 ed. rev. São Paulo: Saraiva, 2000. V.1. p. 415.

21 MARTINS, Fran. Títulos de crédito. 5. ed. Rio de Janeiro: Forense, 1995. V.1, p. 270.

22 TOMAZETTE, Marlon. Curso de direito empresarial: títulos de crédito. 3. ed. São Paulo: Atlas, 2012. V. 2. p.158.

23 BRASIL. Constituição da Republica Federativa do Brasil de 1988. Disponível em: <https://www.planalto.gov.br/ccivil_03/leis/L9492.htm>. Acesso em: 12 out. 2016.

24 BUENO, Sergio Luiz Jose. Tabelionato de protesto. 2 ed. São Paulo: Saraiva, 2016. p. 70. 
normalmente não ocorre ao menos se mostra necessária a intervenção judicial em todo o decorrer do procedimento.

$\mathrm{O}$ ato do protesto deve ser lavrado e registrado com as exigências fixadas nos artigo n 22 e 23, da Lei no 9.492/1997, por isso caracteriza-se como ato formal.

O artigo no 22 da referida Lei, diz respeito aos dados que devem conter no instrumento de protesto, e em seu parágrafo único trata-se referente à dispensa da transcrição do documento quando sua imagem for conservada no arquivo do Tabelionato de Protesto de Títulos, e dispõem o que segue:

Art. 22. O registro do protesto e seu instrumento deverão conter:

I - data e número de protocolização;

II - nome do apresentante e endereço;

III - reprodução ou transcrição do documento ou das indicações feitas pelo apresentante e declarações nele inseridas;

IV - certidão das intimações feitas e das respostas eventualmente oferecidas;

$V$ - indicação dos intervenientes voluntários e das firmas por eles honradas;

VI - a aquiescência do portador ao aceite por honra;

VII - nome, número do documento de identificação do devedor e endereço;

VIII - data e assinatura do Tabelião de Protesto, de seus substitutos ou de Escrevente autorizado.

Parágrafo único. Quando o Tabelião de Protesto conservar em seus arquivos gravação eletrônica da imagem, cópia reprográfica ou micrográfica do título ou documento de dívida, dispensa-se, no registro e no instrumento, a sua transcrição literal, bem como das demais declarações nele inseridas. ${ }^{25}$

Quanto ao registro dos termos dos protestos, refere-se o artigo no 23 da Lei, com o seguinte teor:

Art. 23. Os termos dos protestos lavrados, inclusive para fins especiais, por falta de pagamento, de aceite ou de devolução serão registrados em um único livro e conterão as anotações do tipo e do motivo do protesto, além dos requisitos previstos no artigo anterior. ${ }^{26}$

25 BRASIL. Lei no 9.492, de 10 de setembro de 1997. Define competência, regulamenta os serviços concernentes ao protesto de títulos e outros documentos de dívida e dá outras providências. Disponível em: <https://www.planalto.gov.br/ccivil_03/leis/L9492.htm>. Acesso em: 06 nov. 2016.

26 BRASIL. Lei no 9.492, de 10 de setembro de 1997. Define competência, regulamenta os serviços concernentes ao protesto de títulos e outros documentos de dívida e dá outras providências. Disponível em: <https://www.planalto.gov.br/ccivil_03/leis/L9492.htm>. Acesso em: 06 nov. 2016. 
Não contendo as informações exigidas, o protesto pode ser objeto de cancelamento por determinação judicial ou administrativa.

O protesto é considerado uno, pois é realizado em um ato só, seu objeto é o título ou documento de dívida. Portanto é correto afirmar que o Tabelião protestou o cheque, ou seja, o documento e não o emitente do documento. Luiz Emygdio Rosa Jr explica que:

O protesto é também ato unitário, porque deve ser realizado em um único momento, e quando efetuado em relação ao devedor principal não necessita ser reeditado no que concerne ao sacador, endossantes e respectivos avaliastes. $^{27}$

O artigo $3^{\circ}$ da Lei ำ 9.492/97, fala sobre a competência do Tabelião de Protesto, quanto ao procedimento, que assim dispõem:

\begin{abstract}
Art. $3^{\circ}$ Compete privativamente ao Tabelião de Protesto de Títulos, na tutela dos interesses públicos e privados, a protocolização, a intimação, o acolhimento da devolução ou do aceite, o recebimento do pagamento, do título e de outros documentos de dívida, bem como lavrar e registrar o protesto ou acatar a desistência do credor em relação ao mesmo, proceder às averbações, prestar informações e fornecer certidões relativas a todos os atos praticados, na forma desta Lei. ${ }^{28}$
\end{abstract}

Portanto, entende-se que o protesto é um ato notarial com relação à lavratura, e também um ato de registro, podendo ser considerado um ato misto, pois englobam as duas figuras anteriores. Partindo desta ideia, é possível afirmar que o protesto não é primeiro lavrado para depois ser registrado, são atos concomitantes. O Tabelião ao mesmo tempo em que lavra o presto o registra.

O protesto pode ser obrigatório ou facultativo. Protesto obrigatório é o que não pretende apenas comprovar a falta ou recusa de aceite ou pagamento. Existem situações em que o protesto é obrigatório, como por exemplo: I - Para requerer, a

27 ROSA JÚNIOR, Luiz Emygdio Franco da. Títulos de crédito. 5. ed., ver.e atual. de acordo com o novo código civil. Rio de Janeiro: Renovar, 2009.p. 386.

28 BRASIL. Lei no 9.492, de 10 de setembro de 1997. Define competência, regulamenta os serviços concernentes ao protesto de títulos e outros documentos de dívida e dá outras providências. Disponível em: <https://www.planalto.gov.br/ccivil_03/leis/L9492.htm>. Acesso em: 06 nov. 2016. 
falência do devedor (artigo no 94, I, da Lei no 11.101/2005) 29 ; II - A hipótese prevista

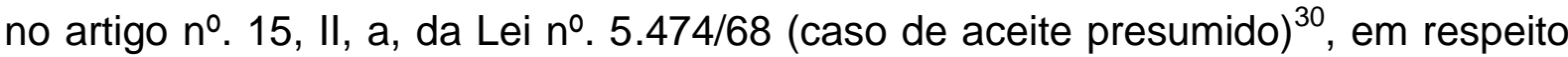
de duplicatas sem aceite, para que tenha força executiva é preciso que o credor prove que a instituição financeira remeteu o título ao devedor, que a mercadoria vendida ou o serviço prestado foram recebidos e que o protesto da duplicata se consumou, e ainda que não ocorresse a oposição do comprador em relação à venda e compra mercantil ou a prestação de dito serviço. É necessário o protesto no caso da duplicata sem aceite, visto que se não atendidos os pressupostos, a duplicata sem aceite não terá força executiva; e III - No caso do artigo №. 13, §4ํㅜㄹ da Lei no $5.474 / 68^{31}$, das duplicatas, que regulam o direito de regresso do credor contra o sacador da cártula.

Pode-se entender que o protesto obrigatório é quando a lei o exige pra resguardo de direitos cambiais. Protesto facultativo é todo aquele que o credor não necessita do protesto para exigir em juízo a obrigação constante no título cambial, ou seja, o ato é apenas para comprovar que o devedor não cumpriu com sua obrigação. Teria somente uma função probatória. Deste modo, facultativo é quando o credor pode exigir o cumprimento da obrigação, sem o mesmo, em juízo.

29 BRASIL. Lei no 11.101, de 09 de fevereiro de 2005. Regula a recuperação judicial, a extrajudicial e a falência do empresário e da sociedade empresária. Disponível em: <https://www.planalto.gov. br/ccivil_03/_ato2004-2006/2005/lei//11101.htm>. Acesso em: 07 nov. 2016. Art. 94. Será decretada a falência do devedor que: I - sem relevante razão de direito, não paga, no vencimento, obrigação líquida materializada em título ou títulos executivos protestados cuja soma ultrapasse o equivalente a 40 (quarenta) salários-mínimos na data do pedido de falência.

30 BRASIL. Lei no $\mathbf{5 . 4 7 4}$, de 18 de julho de 1968. Dispõe sobre as Duplicatas, e dá outras providências. Disponível em: <https://www.planalto.gov.br/ccivil_03/leis/L5474.htm>. Acesso em: 07 nov. 2016. Art. 15 - A cobrança judicial de duplicata ou triplicata será efetuada de conformidade com o processo aplicável aos títulos executivos extrajudiciais, de que cogita o Livro II do Código de Processo Civil, quando se tratar:... II - de duplicata ou triplicata não aceita, contanto que, cumulativamente:a) haja sido protestada.

31 BRASIL. Lei no 5.474, de 18 de julho de 1968. Dispõe sobre as Duplicatas, e dá outras providências. Disponível em: <https://www.planalto.gov.br/ccivil_03/leis/L5474.htm>. Acesso em 07 nov. 2016. Art. 13. A duplicata é protestável por falta de aceite de devolução ou pagamento... § 4 O portador que não tirar o protesto da duplicata, em forma regular e dentro do prazo de 30 (trinta) dias, contado da data de seu vencimento, perderá o direito de regresso contra os endossantes e respectivos avalistas. 


\title{
4 IMPOSTO PREDIAL E TERRITORIAL URBANO - IPTU
}

O IPTU, Imposto Predial e Territorial Urbano é uma espécie de imposto, tem regulamento entre os artigos 32 a 34 do Código Tributário Nacional, Lei ㄲo 5.172, de 25 de outubro de 1966, onde se trata da competência dos efeitos do fato gerador da base de cálculo e do contribuinte.

O artigo no 32 da Lei descreve sobre o fato gerador do IPTU, veja-se:

\begin{abstract}
Art. 32. O imposto, de competência dos Municípios, sobre a propriedade predial e territorial urbana tem como fato gerador a propriedade, o domínio útil ou a posse de bem imóvel por natureza ou por acessão física, como definido na lei civil, localizado na zona urbana do Município.

$\S 1^{\circ}$ Para os efeitos deste imposto, entende-se como zona urbana a definida em lei municipal; observado o requisito mínimo da existência de melhoramentos indicados em pelo menos 2 (dois) dos incisos seguintes, construídos ou mantidos pelo Poder Público:

I - meio-fio ou calçamento, com canalização de águas pluviais;

II - abastecimento de água;

III - sistema de esgotos sanitários;

IV - rede de iluminação pública, com ou sem posteamento para distribuição domiciliar;

V - escola primária ou posto de saúde a uma distância máxima de 3 (três) quilômetros do imóvel considerado.

$\S 2^{\circ}$ A lei municipal pode considerar urbanas as áreas urbanizáveis, ou de expansão urbana, constantes de loteamentos aprovados pelos órgãos competentes, destinados à habitação, à indústria ou ao comércio, mesmo que localizados fora das zonas definidas nos termos do parágrafo anterior. ${ }^{32}$
\end{abstract}

A base de cálculo do imposto sobre a propriedade predial e territorial urbana é o valor venal do imóvel, conforme é claro o artigo o 33 do Código Tributário Nacional:

\begin{abstract}
A base do cálculo do imposto é o valor venal do imóvel.
Parágrafo único. Na determinação da base de cálculo, não se considera o valor dos bens móveis mantidos, em caráter permanente ou temporário, no imóvel, para efeito de sua utilização, exploração, aformoseamento ou comodidade. ${ }^{33}$
\end{abstract}

32 BRASIL. Lei no 5.172, de 25 de outubro de 1966. Dispõe sobre o Sistema Tributário Nacional e institui normas gerais de direito tributário aplicáveis à União, Estados e Municípios. Disponível em: <https://www.planalto.gov.br/ccivil_03/leis/L5172.htm>. Acesso em: 26 maio 2016.

33 BRASIL. Lei no 5.172, de 25 de outubro de 1966. Dispõe sobre o Sistema Tributário Nacional e institui normas gerais de direito tributário aplicáveis à União, Estados e Municípios. Disponível em: <https://www.planalto.gov.br/ccivil_03/leis/L5172.htm>. Acesso em: 26 maio 2016. 


\title{
O Código Tributário Nacional define em seu artigo no 34, "que contribuinte do
} imposto é o proprietário do imóvel, o titular do seu domínio útil, ou o seu possuidor a qualquer título." ${ }^{34}$ Segundo o autor Hugo de Brito Machado, "a função do imposto sobre a propriedade predial e territorial urbano é tipicamente fiscal. Seu objetivo primordial é a obtenção de recursos financeiros para os municípios." ${ }^{35} \mathrm{~A}$ Constituição Federal de 1988, traz claramente a respeito da competência aos municípios a instituir impostos sobre propriedade predial e territorial urbano, em seu art. no 156 , inciso I. ${ }^{36}$

Portanto, conclui-se que o IPTU é um imposto, tributo e tem suas normas jurídicas na Constituição Federal, e no Código Tributário Nacional. Por ser um tributo municipal, é regulado por lei ordinária especifica de cada município. Define-se dívida ativa tributária no Artigo 39, § 2, da Lei n. ${ }^{\circ}$ 4.320, de 17 de março de 1964, veja-se:

\begin{abstract}
Dívida Ativa Tributária é o crédito da Fazenda Pública dessa natureza, proveniente de obrigação legal relativa a tributos e respectivos adicionais e multas, e Dívida Ativa não Tributária são os demais créditos da Fazenda Pública, tais como os provenientes de empréstimos compulsórios, contribuições estabelecidas em lei, multa de qualquer origem ou natureza, exceto as tributárias, foros, laudêmios, alugueis ou taxas de ocupação, custas processuais, preços de serviços prestados por estabelecimentos públicos, indenizações, reposições, restituições, alcances dos responsáveis definitivamente julgados, bem assim os créditos decorrentes de obrigações em moeda estrangeira, de subrogação de hipoteca, fiança, aval ou outra garantia, de contratos em geral ou de outras obrigações legais. ${ }^{37}$
\end{abstract}

A certidão de dívida ativa é o documento expedido pelo ente público para permitir a cobrança de tributos, e regulamentada pela Lei 6.830/1980, se configura título executivo extrajudicial, conforme art. 784 do Código de Processo Civil. Até

${ }^{34}$ BRASIL. Lei no 5.172, de 25 de outubro de 1966. Dispõe sobre o Sistema Tributário Nacional e institui normas gerais de direito tributário aplicáveis à União, Estados e Municípios. Disponível em: <HTTPS://www.planalto.gov.br/ccivil_03/leis/L5172.htm>. Acesso em: 26 maio 2016.

35 MACHADO, Hugo de Brito. Curso de direito tributário. 31. ed. rev. atual. e ampl. São Paulo: Malheiros, 2010. p. 411:

36 BRASIL. Constituição da Republica Federativa do Brasil de 1998. Disponível em: $<$ https://www.planalto.gov.br/ccivil_03/constituicao/constituicao.htm>. Acesso em: 12 ou. 2016. Art. 156. Compete aos Municípios instituir impostos sobre: I - propriedade predial e territorial urbana;

${ }^{37}$ BRASIL. Lei no 4.320 de 17 de março de 1964. Estatui Normas Gerais de Direito Financeiro para elaboração e controle dos orçamentos e balanços da União, dos Estados, dos Municípios e do Distrito Federal. Disponível em: <http://www.planalto.gov.br/ccivil_03/leis/L4320.htm>. Acesso em: 07 nov. 2016. 
entrar em vigor a Lei no 9.492 de 10 de setembro de 1997, não existiam possibilidade alguma de protestar qualquer outro tipo de documento a não ser os previsto na legislação processual.

Com a vigência da Lei, veio uma novidade, mencionada no seu art. 1ํㅜ 0 protesto como ato formal e solene que faria prova da inadimplência e do descumprimento de uma obrigação que tivesse origem em um título ou em outros documentos de dívida.

Com essa expressão "outros documentos de dívidas", criou-se uma discussão com relação à ampliação de seu conceito. Onde havia a duvida de qual tipo de documento de divida seria possível de ser protestado? Pois o legislador foi omissão neste ponto. $\mathrm{E}$ até hoje não há um consenso de que possa denominar exatamente o que são documentos de dívida.

O autor Carlos Henrique Abraão é bem abrangente quanto ao tema, e se manifesta da seguinte maneira:

Refletidamente, portanto, quaisquer títulos ou documentos que alicerçam obrigações liquidas, certas, exigíveis, fazer parte dos indicativos instrumentalizados ao protesto, coro exame primeiro de suas condições caberá ao Tabelião, formalizando o ato ou recusando sua lavratura. ${ }^{38}$

No mesmo sentido se expressa o autor Eduardo Pacheco Ribeiro de Souza:

Considerando que a Lei foi editada no momento que a busca por meios simples, rápidos e menos onerosos para os interessados solucionarem conflitos de interesses é evidente, considerando que a realidade das relações jurídicas envolvendo débito e crédito exige segurança e solução célere para os conflitos, e considerando que não há palavras inúteis na lei, que se refere em diversos dispositivos aos documentos de divida, não se pode emprestar a expressão interpretação restritiva sem amparo na lei. ${ }^{39}$

Pode-se concluir que, documento de dívida é todo título executivo judicial ou extrajudicial, ou qualquer outro documento cujo protesto seja permitido por lei ou por norma regulamentar.

38 ABRAÃO, Carlos Henrique. Protesto: caracterização de mora, inadimplemento obrigacional. 4. ed. São Paulo: Atlas, 2011. p. 14.

39 SOUZA, Eduardo Pacheco Ribeiro de. Noções fundamentais de direito registral e notarial. São Paulo, SP: Saraiva, 2011. p. 185. 


\section{LEI № 12.767/2012}

O protesto notarial das certidões de dívida ativa (CDA) foi um tema muito discutido, apesar de o Conselho Nacional de Justiça ter se posicionado ela protestabilidade das CDA's. ${ }^{40}$ O Supremo Tribunal de Justiça, em especial, sempre apresentou uma resistência jurisdicional, e em varias situações deixou claro que o protesto da CDA era medida inócua e desnecessária, faltando interesse ao Ente Público que se justificasse o protesto para a satisfação do crédito tributário. ${ }^{41}$

Referindo-se a Lei Estadual (SP), o autor Emanoel Macabu Moraes, conclui mais restritivamente que "em face da analise sistemática e mesmo teleológica da legislação pátria, parece-nos quer o legislador paulista está no caminho correto. Só será possível protestar documentos de divida que configurem titulo executo judicial ou extrajudicial". ${ }^{42}$

Recentemente a questão foi totalmente pacificada com a edição da Lei ํo 12.767 de 27 de dezembro de 2012, que trouxe em seu art. no 25 a inclusão do parágrafo único no art. $1^{\circ}$ da Lei $n^{\circ}$ 9.492/1997, com o seguinte teor "Incluem-se entre os títulos sujeitos a protesto as certidões de dívida ativa da União, dos Estados, do Distrito Federal, dos Municípios e das respectivas autarquias e fundações públicas".

Embora não obrigatório, o protesto da CDA deveria ser melhor explorado, face às vantagens que constituem sua efetivação: celeridade do processo de cobrança, celeridade da recuperação do crédito e contribuição para o Princípio da Economia Processual. "Para o Desembargador Eutálio Porto, 'o gasto com a execução acaba sendo maior do que o próprio débito', e desta forma, fere ao Princípio da Economia Processual". 43

40 CNJ - Pedido de Providencias 200910000045376, rel. Conselheira Morgana Richa.

41 Vide, dentre outros, os seguintes julgados: Resp, 1.093.601 - RJ, rel. Min. Eliana Calmon, j. 18.11.2008; Resp 287.827-MG, rel Min. Francisco Falcão, j. 20.10.2005; AgRg no Ag 936.606-PR, rel. Min José Delgado, j. 06.05.2008

42 MORAES, Emanoel Macabu. Protesto extrajudicial. Rio de Janeiro: Lumen Juris, 2004, p. 35

43 LAMANAUSKAS; GUÉRCIO NETO apud GABRIELE, Mauricio. O protesto notarial de certidões da dívida ativa: entre a crise do judiciário e a eficiência da administração pública. Disponível em: <httpshttp://www.publicadireito.com.br/artigos/?cod=c5a73f074ec0f725>. Acesso em: 07 nov. 2016. 
Com a possibilidade legal do protesto das CDAs, possibilita os tabeliães de protesto a colaborarem com o Poder Público, com relção a recuperação do crédito da Fazenda Pública, atendendo o intuito no Noco Código de Processo Civil, ao clamor pelo desafogo do Judicário e redução da judicialização.

Dentre outras vantagens do protesto da Certidão de Divida Ativa, merecem destaque: a gratuídade, o credor apresentante do titulo, não o acarretará valores valores para protestar, terá apenas custo se vier a desistir do protesto, conforme artigo $2^{\circ}$ do Provimento n 19/2014 da Corregedoria Geral da Justiça do Rio Grande do Sul, que acrescentou o art. no 714-C, na Consolidação Normativa Notarial e Registral do Rio Grande do Sul ${ }^{44}$; agilidade na recuperação dos créditos e maior eficácia, ou seja, em pequeno prazo ha resposta do credor quando ao pagamento da divida inadimplida, tempo esse extremamente menor quanto ao tempo do processo de execução; disciplina do contribuinte, pois as dividas no Poder Público, costumeiramente são deixadas em último lugar, pois pelos costumes, esse tipo de divida leva mais tempo para cobrança.

O Plenário do Supremo Tribunal Federal (STF) julgou improcedente a Ação Direta de Inconstitucionalidade (ADI) 5135. Por 7 votos a 3, ministros decidiram que método de cobrança usado pela Fazenda Pública não contraria a ampla defesa nem constitui sanção política. ${ }^{45} \mathrm{O}$ julgamento iniciou no dia 03 de novembro de 2016 . $\mathrm{O}$ Plenário da corte finalizou no dia 09 de novembro de 2016 o julgamento da referida ação de incostitucionalidade, movida pela Confederação Nacional da Indústria (CNI), publicando a seguinte decisão de julgamento:

O Tribunal, por maioria e nos termos do voto do Relator, julgou improcedente o pedido formulado, vencidos os Ministros Edson Fachin, Marco Aurélio e Ricardo Lewandowski. Fixada tese nos seguintes termos: "O protesto das Certidões de Dívida Ativa constitui mecanismo

44 Art. 714- C - O valor dos emolumentos e demais despesas serão pagos pelos devedores, devendo - Titular lançar selo digital combinado com o código PEPO (pagamento de emolumentos a posteriori). COLÉGIO REGISTRAL DO RIO GRANDE DO SUL. Provimento no 19/2014: expediente 0010-10/001089-7. Disponível em: <http://www.colegioregistralrs.org.br/publicacoes/ provimentoCompleta?id=15410>. Acesso em: 07 nov. 2016.

45 BRASIL. Supremo Tribunal Federal. Protesto de certidões de dívida ativa é constitucional, decide STF. Disponível em: <www.stf.jus.brqportalqcmsqverNoticaDetalhe.aspidConteudo $=329103>$. Acesso em: 10 nov. 2016 . 
constitucional e legítimo, por não restringir de forma desproporcional quaisquer direitos fundamentais garantidos aos contribuintes e, assim, não constituir sanção política". O Ministro Marco Aurélio, vencido no mérito, não participou da fixação da tese. Ausentes, justificadamente, os Ministros Gilmar Mendes e Teori Zavascki, participando em missão oficial do Programa de Eleições dos Estados Unidos (USEP) e da $7^{\text {ạ }}$ Conferência da Organização Global de Eleições (GEO-7), em Washington, Estados Unidos, e o Ministro Dias Toffoli, acompanhando as eleições norte-americanas a convite da International Foundation for Electoral Systems (IFES). Presidiu o julgamento a Ministra Cármen Lúcia. Plenário, 09.11.2016. ${ }^{46}$

Desde modo, verifica-se como constitucional o protesto da Certidão de Dívida ativa. O ministro Barroso destacou que a cobrança extrajudicial também não representa violação do devido processo legal, como alegou a CNI. Segundo ele, o fato de existir uma via de cobrança judicial da dívida com a Fazenda Pública não significa que seja a única via admitida para a recuperação de créditos tributários ou que deva ser exclusiva. "O fato de haver o protesto não impede o devedor, o contribuinte, de questionar judicialmente a dívida ou a legitimidade do próprio protesto", afirmou. O relator salientou que a cobrança extrajudicial, por meio de protesto, é uma modalidade menos invasiva aos direitos do devedor que uma execução fiscal, que permite a penhora dos bens do devedor até o limite da dívida desde a propositura da ação judicial. ${ }^{47}$

\section{PROCEDIMENTOS PARA O PROTESTO DA CERTIDÃO DE DÍVIDA ATIVA}

Com essa possibilidade que a Lei nos traz, do protesto da certidão de dívida, é necessário saber como ocorre esse processo junto ao Tabelionato de Protesto.

A certidão de dívida ativa, com vencimento para o ultimo dia do mês, juntamente com a guia de arrecadação serão apresentadas até o dia dez de cada mês no Tabelionato de Protesto da comarca do domicílio do contribuinte para apontamento por meio da Central de Remessa de Arquivo - CRA. A central de

46 BRASIL. Supremo Tribunal Federal. Adi 5135 - Ação Direta de Inconstitucionalidade. Disponível em: <http://www.stf.jus.br/portal/processo/verProcessoAndamento.asp?numero=5135\& classe $=A D \mid \&$ origem $=A P \&$ recurso $=0$ \&tipoJulgamento $=M>$. Acesso em: 10 nov. 2016.

47 BRASIL. Supremo Tribunal Federal. STF inicia julgamento de ADI que questiona protesto de certidão de dívida ativa. Disponível em: <http://www.stf.jus.br/portal/cms/verNoticiaDetalhe.asp? idConteudo=328657\&caixaBusca=N $>$. Acesso em: 10 nov. 2016. 
remessa de arquivo foi criada pelo IEPRO - Instituto de Estudos de Protestos, para receber da União, Estados e Municípios as certidões de dívida ativa.

\subsection{Central de Remessa de Arquivo - CRA}

A Central de Remessa de Arquivos é um ambiente virtual, ou seja, um sistema muito bem informatizado que faz a distribuição das certidões de dívida, pelos endereços dos devedores, e a comunicação entre credores/apresentantes e os Tabelionatos de Protesto. A CRA é de responsabilidade da IEPRO - RS, que é correspondente em nível estadual do Instituto de Estudos de Protesto do Brasil IEPBT.

Primeiramente para protestar uma Certidão de dívida ativa, o Município deve firmar um convênio com o IEPRO - RS, e enviar para o órgão os documentos exigidos e assinados.

A CRA envia as certidões de dívida ativa, por meio eletrônico ao Tabelionato, para que ocorra um exame formal dos documentos apresentados. Se houver alguma irregularidade, o mesmo será devolvido ao apresentante para que a irregularidade seja corrigida, se estiver tudo na devida ordem, será encaminhado um arquivo de confirmação informando o protocolo do título.

\subsection{Apontamento}

A Central de Remessa de Arquivo - CRA enviará ao Tabelionato de Protesto por meio eletrônico um arquivo e as imagens necessárias para apontamento da certidão de dívida ativa. É enviada juntamente com a certidão de dívida ativa, uma guia com código de barras, que se houver o pagamento do boleto ao Tabelionato de Protesto, o Tabelião efetuará a quitação desta guia, repassando o dinheiro para o Município apresentante.

O apresentante, neste caso o Município, pode desistir do apontamento de determinado título caso seja constatado algum erro na apresentação, ou cancelar protestos indevidos caso seja identificado. 
A certidão de dívida ativa pode ficar como situação de apontada no sistema do Tabelionato de Protesto até o vigésimo quinto dia de cada mês, pois até o último dia útil do mês o Tabelião tem que enviar um retorno para a Central de Remessa de Arquivo - CRA. O título deve ser enviado até o último dia de cada mês, tendo em vista o valor da dívida, que de mês a mês acrescenta juros e ocorre alteração de valores.

\subsection{Intimação}

Posterior ao apontamento da certidão de dívida ativa no sistema do Tabelionato de Protesto será emitida uma intimação, que deverá ser entregue no endereço do devedor informado pelo apresentante. Se por algum motivo a intimação não for entregue, não estando devedor no local, não residindo mais na cidade, ou qualquer outra situação constante na Lei, o cartório tem a possibilidade de publicação de edital, publicado o edital a intimação é considerada cumprida.

A intimação deve preencher os requisitos constituídos no artigo no 14 da Lei no 9.492/97 no parágrafo $§ 2^{\circ}$. O texto do artigo traz o seguinte:

Protocolizado o título ou documento dívida, o tabelião de protesto expedirá a intimação ao devedor, no endereço fornecido pelo apresentando do título ou documento, considerando-se cumprida quando comprovada a sua entrega no mesmo endereço. ${ }^{48}$

Há quem entenda que a intimação deve ser pessoal diretamente ao destinatário. Com base no princípio da formalidade simplificada, o legislador diz que é suficiente a entrega da intimação no endereço do devedor, a quem ali se encontrar. O legislador entende que se a lei exigisse intimação pessoal, o texto seria o seguinte: "considerada cumprida quando comprovada sua entrega a ele." 49 Não sendo o que diz a Lei, e considera cumprida a intimação quando sua entrega comprovada no endereço fornecido pelo apresentado.

48 BRASIL. Lei no 9.492, de 10 de setembro de 1997. Define competência, regulamenta os serviços concernentes ao protesto de títulos e outros documentos de dívida e dá outras providências. Disponível em: <https://www.planalto.gov.br/ccivil_03/leis/L9492.htm>. Acesso em: 31 maio 2017.

49 BUENO, Sergio Luiz Jose. Tabelionato de protesto. 2. ed. São Paulo: Saraiva, 2016.p. 206.

\section{DIREITO, CULTURA E CIDADANIA}

Osório, v. 7, n. 1, 2017 

o seguinte:

Não é necessário o recebimento pessoal pelo devedor, pois regular a intimação, quando o aviso, entregue no endereço indicado, for recebido pela esposa, empregada da residência, enfim, por qualquer pessoa (artigo № 14 da Lei $9.9492 / 97)^{50}$

Ou seja, sendo entregue a intimação no endereço indicado pelo apresentante do título, será considerada a intimação concluída. Via de regra, o endereço considerado é o indicado pelo apresentante sob pena de responsabilidade, nos

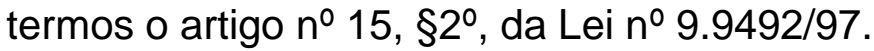

O artigo $n^{0} 15$ da Lei do Protesto fala sobre a intimação por edital:

\begin{abstract}
A intimação será feita por edital se a pessoa indicada para aceitar ou pagar for desconhecida, sua localização incerta ou ignorada, for residente ou domiciliada fora da competência territorial do tabelionato, ou ainda, ninguém se dispuser a receber a intimação no endereço fornecido pelo apresentante. 51
\end{abstract}

Portanto, a intimação pode ser pessoal, quando o aviso é entregue no endereço fornecido pelo apresentante, e pode ser por edital, quando após as três tentativas de localização do devedor for ineficaz, ou seja, por algum dos motivos contidos na lei o mesmo não for localizado. A lei ainda traz a possibilidade da intimação pelo correio, sendo essa uma opção do titular do Tabelionato de Protesto, ou seja, não é obrigatória a intimação via correios.

\title{
6.4 Pagamento
}

Cumprida a intimação, o devedor terá o prazo de três dias úteis para efetuar o pagamento da referida dívida em cartório através do boleto bancário que será entregue junto com a intimação.

50 AMADEI, Vicente de Abreu; DIP, Ricardo (Coord.) et al. Introdução ao direito notarial e registral. Porto Alegre: Fabris, 2004. p. 112.

51 BRASIL. Lei no 9.492, de 10 de setembro de 1997. Define competência, regulamenta os serviços concernentes ao protesto de títulos e outros documentos de dívida e dá outras providências. Disponível em: <https://www.planalto.gov.br/ccivil_03/leis/L9492.htm>. Acesso em: 30 maio 2017. 
Se efetuado o pagamento, o valor será creditado na conta corrente do Tabelionato de Protesto. Entrando no sistema o referido pagamento, o Tabelião deverá emitir através do sistema da CRA a guia para pagamento da dívida.

Quando o Tabelião efetuar o pagamento da referida dívida o devedor automaticamente quitará seu débito com o Município, não sendo o contribuinte protestado, ou seja, o Tabelião terá feito apenas uma prestação de serviço para o Município cobrando a referida dívida.

\subsection{Cancelamento, Desistência ou Sustação}

Dentro do prazo de três dias úteis o credor pode desistir do protesto, tendo em vista a procura do devedor com o credor para negociar a referida dívida. Podendo também, nesse prazo de três dias o devedor obter uma ordem judicial para sustação do protesto. Terminado o referido prazo, se não ocorrer nenhuma das situações anteriores, o documento de dívida será protestado.

Pode ocorrer em quanto não protestado a certidão de dívida ativa, a negociação da dívida diretamente com o credor, onde o mesmo deverá informar ao devedor da necessidade da quitação dos emolumentos junto ao Tabelionato, ocorrendo assim à desistência do protesto da certidão de dívida ativa.

Se acontecer a negociação da dívida posterior ao Protesto o apresentante envia pela CRA a autorização de cancelamento. Após o protesto o contribuinte não poderá realizar o pagamento em cartório, deverá negociar diretamente com o credor, e comparecer no Tabelionato de Protesto apenas para arcar com os emolumentos do apontamento, ocorrendo nessa situação o cancelamento do protesto da certidão de dívida ativa.

O contribuinte após receber a intimação pode verificar alguma irregularidade no título, ou na dívida que lhe será cobrada, procurando assim a resolução do problema por meio judicial. No decorrer do processo o juiz pode emitir um ofício direcionado ao Tabelionato com o pedido de sustação dos efeitos do protesto onde interromperá os referidos prazos, e efeitos, até a finalização do processo judicial e resolução da lide. 


\section{CONSIDERAÇÕES FINAIS}

Sem a pretensão de esgotar o assunto objeto da presente pesquisa, tão somente o de fomentar a discussão e o debate sobre o tema, observou-se que a doutrina e a legislação passaram por várias mudanças quanto o protesto da certidão de dívida ativa utilização.

Todavia, podemos concluir que o Direito Notarial, na figura do tabelião, é uma das mais sólidas instituições do direito brasileiro, e na fé pública que é inerente ao seu titular reside talvez à maior garantia possível em termos probatórios. Além do mais, por seu caráter privado e pela responsabilidade civil que recai na pessoa do notário, os negócios celebrados perante este profissional são verificados por agente competente e qualificado para tanto, garantindo ao negócio jurídico a validade e eficácia pretendida pelas partes. A atividade notarial tem sua legislação própria.

O Tabelião de Protesto tem sua responsabilidade configurada como subjetiva diferente da do Tabelião de Notas. É subjetiva a responsabilidade subjetiva do Tabelião de Protesto, pois o mesmo não emite a certidão de dívida ativa somente Ihe é atribuído a função de cobrança da mesma. Por isso para o mesmo ser responsabilizado deverá ser provado o dolo ou a culpa ao praticar sua função. Tendo responsabilidade objetiva o apresentante do título.

$\mathrm{O}$ ato do protesto em si, nada mais é que a prova da inadimplência e o descumprimento da obrigação do contribuinte, baseada em títulos e qualquer outro documento de dívida, tendo sua base jurídica em lei própria 9.492/1997, sendo um ato solene, e público, sua característica principal é comprovar que o devedor não cumpriu regularmente com sua obrigação contratual.

O IPTU, Imposto Predial e Territorial Urbano é um imposto, tem regulamento no Código Tributário Nacional, e na Constituição Federal, e por ser um tributo municipal é regulada por Lei específica de cada município. A base de cálculo do imposto sobre a propriedade predial e territorial urbana é o valor venal do imóvel.

Sendo o contribuinte o proprietário do imóvel e não arcando com suas obrigações junto com o município se tornará devedor de impostos. Com essa 
inadimplência o ente público poderá emitir uma certidão de dívida ativa para permitir a cobrança do referido tributo.

Houve grandes discussões doutrinárias e judiciais, com relação ao tema. Ocorrendo a necessidade da edição da Lei no 12.767/2012, que em seu artigo no 25 trouxe a inclusão do parágrafo único da Lei n 9.492/1997, se tornando totalmente pacificada a questão.

Mesmo não obrigatório o protesto da Certidão de Dívida Ativa Municipal, é de grande relevância, pois os Municípios têm uma forma muito célere e eficaz da cobrança de valores que podem contribuir para resolução de diversos problemas e efetuar grandes melhorias nos mesmos. Nem se falando das outras vantagens como a gratuidade para tal cobrança.

Atualmente foi criada a Central de Remessa de Arquivo - CRA, e por meio desta ocorre à distribuição e envio das referidas certidão ao Tabelionato de Protesto. Ocorrendo uma comunicação entre a CRA e os Municípios, tendo o Tabelionato de Protesto somente comunicação direita com a instituição e não com o Ente Público com relação ao procedimento do protesto.

Nesse sentido, se faz importante ter conhecimento do procedimento do protesto. Com o estudo podemos notar que a existem diversos passos até o protesto da certidão de dívida ativa. Primeiramente ocorre o apontamento do documento de dívida, posterior a intimação, tem a possibilidade de ocorrer ou não o pagamento, e ainda o cancelamento a desistência ou a sustação, e finalmente se não ocorrer nenhuma das situações o protesto do mesmo.

Ante o exposto, conclui-se com clareza que protestar a certidão de dívida ativa mostra aos contribuintes, que pagar seus impostos é de extrema importância, pois medidas efetivas estão sendo tomadas contra os inadimplentes. Nota-se o quanto desafogará o Judiciário, que com o meio extrajudicial de cobrança, retira das varas de execução diversas ações, ocorrendo com isso, uma melhor prestação jurisdicional. Com o protesto da Certidão de Dívida Ativa o contribuinte terá seu nome negativado e uma grande restrição financeira, o que ocorrerá procura imediata até o credor. 


\section{REFERÊNCIAS}

ABRAÃO, Carlos Henrique. Protesto: caracterização de mora, inadimplemento obrigacional. 4. ed. São Paulo: Atlas, 2011.

AMADEI, Vicente de Abreu; DIP, Ricardo (Coord.) et al. Introdução ao direito notarial e registral. Porto Alegre: Fabris, 2004.

BRANDELLI, Leonardo. Teoria geral do direito notarial. 2. ed. São Paulo: Saraiva, 2007.

BRASIL. Constituição da Republica Federativa do Brasil de 1988. Ato das

Disposições Constitucionais Transitórias. Disponível em: <https://www.planalto.gov. br/ccivil_03/leis/L9492.htm>. Acesso em: 12 out. 2016.

BRASIL. Lei no 11.101, de 09 de fevereiro de 2005. Regula a recuperação judicial, a extrajudicial e a falência do empresário e da sociedade empresária. Disponível em: <https://www.planalto.gov.br/ccivil_03/_ato2004-2006/2005/lei//11101.htm>. Acesso em: 07 nov. 2016.

BRASIL. Lei no 4.320 de 17 de março de 1964. Estatui Normas Gerais de Direito Financeiro para elaboração e controle dos orçamentos e balanços da União, dos Estados, dos Municípios e do Distrito Federal. Disponível em: <http://www.planalto. gov.br/ccivil_03/leis/L4320.htm>. Acesso em: 07 nov. 2016.

BRASIL. Lei no 5.172, de 25 de outubro de 1966. Dispõe sobre o Sistema Tributário Nacional e institui normas gerais de direito tributário aplicáveis à União, Estados e Municípios. Disponível em: <https://www.planalto.gov.br/ccivil_03/leis/ L5172.htm>. Acesso em: 26 maio 2016.

BRASIL. Lei no 5.474, de 18 de julho de 1968. Dispõe sobre as Duplicatas, e dá outras providências. Disponível em: <https://www.planalto.gov.br/ccivil_03/leis/ L5474.htm>. Acesso em: 07 nov. 2016.

BRASIL. Lei no 8.935, de 18 de novembro de 1994. Regulamenta o art. 236 da Constituição Federal, dispondo sobre serviços notariais e de registro. (Lei dos cartórios). Disponível em: <http://www.planalto.gov.br/ccivil_03/leis/L8935.htm>. Acesso em: 29 maio 2017.

BRASIL. Lei no 9.492, de 10 de setembro de 1997. Define competência, regulamenta os serviços concernentes ao protesto de títulos e outros documentos de dívida e dá outras providências. Disponível em: <https://www.planalto.gov.br/ccivil_ 03/leis/L9492.htm>. Acesso em: 04 maio 2017.

BRASIL. Supremo Tribunal Federal. Adi 5135 - Ação Direta de Inconstitucionalidade. Disponível em: <http://www.stf.jus.br/portal/processo/ver 
ProcessoAndamento. asp $?$ numero $=5135 \&$ classe $=A D \mid \&$ origem $=A P \&$ recurso $=0 \&$ tipo $\mathrm{J}$ ulgamento $=M>$. Acesso em: 10 nov. 2016.

BRASIL. Supremo Tribunal Federal. STF inicia julgamento de ADI que questiona protesto de certidão de dívida ativa. Disponível em: <http://www.stf.jus.br/portal/ $\mathrm{cms} /$ verNoticiaDetalhe.asp?idConteudo=328657\&caixaBusca $=\mathrm{N}>$. Acesso em: 10 nov. 2016.

BRASIL. Supremo Tribunal Federal. Protesto de certidões de dívida ativa é constitucional, decide STF. Disponível em: <www.stf.jus.brqportalqcmsqverNotica Detalhe. aspid?Conteudo=329103 >. Acesso em: 10 nov. 2016.

BUENO, Sergio Luiz Jose. Tabelionato de protesto. 2. ed. São Paulo: Saraiva, 2016.

COELHO, Fabio Ulhoa. Curso de Direito Comercial. 3.ed. rev. São Paulo: Saraiva, 2000. V. 1.

COLÉGIO REGISTRAL DO RIO GRANDE DO SUL. Provimento no 19/2014:

expediente 0010-10/001089-7.Disponível em: <http://www.colegioregistralrs.org.br/ publicacoes/provimentoCompleta? id=15410 >. Acesso em: 07 nov. 2016.

GABRIELE, Mauricio. O protesto notarial de certidões da dívida ativa: entre a crise do judiciário e a eficiência da administração pública. Disponível em:

<httpshttp://www.publicadireito.com.br/artigos/?cod=c5a73f074ec0f725>. Acesso em: 07 nov. 2016.

MACHADO, Hugo de Brito. Curso de Direito Tributário. 31. ed. rev., atual. e ampl. São Paulo: Malheiros, 2010.

MARTINS, Fran. Títulos de crédito. 5. ed. Rio de Janeiro: Forense, 1995. V.1.

MIRANDA, Pontes de. Tratado de direito cambiário: duplicata mercantil. 2. ed. Atualizador: Vilson Rodrigues Alves. Campinas: Bookseller, 2001. V. 3.

MORAES, Emanoel Macabu. Protesto extrajudicial. Rio de Janeiro: Lumen Juris, 2004.

PORTO ALEGRE. Foro da Comarca. Expediente no 040111-03.00/07-0, de 07 de agosto de 2007. Expediente instaurado em razão das inúmeras reclamações. Porto Alegre, 07 de agosto de 2007. Disponível em: <http://www.12tabelionato.com.br/dow nload/determinacoes_juiz_diretor_foro_porto_alegre.pdf $>$. Acesso em: 28 maio 2017.

ROSA JUNIOR, Luiz Emygdio Franco da. Títulos de crédito. 4. ed. Rio de Janeiro: Renovar, 2006. 
. Títulos de crédito. 5. ed. rev. e atual. de acordo com o novo código civil. Rio de Janeiro: Renovar, 2010.

RIBEIRO, Luís Paulo Aliende. Regulação da função pública notarial e registral. São Paulo: Saraiva, 2009.

SOUZA, Eduardo Pacheco Ribeiro de. Noções fundamentais de direito registral e notarial. São Paulo, SP: Saraiva, 2011.

TOMAZETTE, Marlon. Curso de direito empresarial: títulos de crédito. 3. ed. São Paulo: Atlas, 2012. V. 2. 